\title{
As reformas processuais e o devido processo legal: incursões sobre a razoável duração do procedimento e a efetividade processual no processo democrático
}

Guilherme César Pinheiro ${ }^{1}$

\section{Resumo}

Esta pesquisa visa estudar a efetividade processual e as implicações trazidas pela garantia da razoável duração do processo. Isso porque tais institutos têm sido compreendidos de forma equivocada, servindo de subterfúgio para o Estado, visto que, sob o argumento de fazer com que o processo tenha duração razoável e, por conseguinte, alcance a efetividade processual, tem-se alterado a legislação procedimental, com o objetivo de suprimir garantias processuais, ao invés de estruturar o Poder Judiciário. Para tanto, é preciso conceituar o instituto do Devido Processo Legal, a fim de compreendê-lo adequadamente no Estado Democrático. Em seguida, trabalhar-se-á o fator "tempo" e a teoria da efetividade processual na principiologia do processo. De resto, será apresentada uma contradita à tradicional compreensão dos fatores que determinam a razoável duração do processo, demonstrando qual é a variável-determinante para o tempo do procedimento.

Palavras-chave: Devido processo legal. Razoável duração do processo. Efetividade processual. Princípios constitucionais do processo. Direitos e garantias fundamentais.

\section{Introdução}

Atualmente, alastra-se pelo Estado brasileiro uma verdadeira onda de alterações das leis processuais. O Código de Processo Civil vigente já sofreu cerca de

1 Graduação em Direito (2010) pela Faculdade Mineira de Direito da Pontifícia Universidade Católica de Minas Gerais. Mestrando em Direito Processual pelo programa de pós-graduação da mesma instituição. Advogado. 
460 alterações legislativas, por meio de 46 leis. $^{2}$ Não é diferente com o Código de Processo Penal, vez que se pretende alterá-lo, parcial ou totalmente, desde 1963, quando Hélio Tornaghi elaborou um anteprojeto que nem chegou a ser encaminhado ao Congresso Nacional. Mas, já se encontram em vigência, desde agosto de 2008, as leis de números 11.689, que alterou a sistemática do procedimento de competência do Tribunal do Júri; 11.690, que diz respeito à gestão de provas no processo penal; e 11.719, que alterou dispositivos referentes à suspensão do processo, ao procedimento, a emendatio libeli e mutatio libeli. ${ }^{3}$ Não bastasse isso, encontram-se em trâmite no Congresso Nacional projetos de leis de alteração total do Código de Processo Civil e Processo Penal, respectivamente, o Projeto de Lei do Senado 166/2010 e o Projeto de Lei do Senado 156/09.

Nessa linha de pensamento, foi inserido pela Emenda à Constituição no 45 de 2004, o princípio da razoável duração do processo e os meios que garantem sua célere tramitação (art. 5 , LVIII). Segundo o Título II da Constituição, o referido princípio é direito fundamental ${ }^{4}$ dos cidadãos, porém parece que o legislador ordinário não compreendeu bem isso, porque, paradoxalmente, alegando que busca garantir a razoável duração do processo e, consequentemente, atingir a efetividade do processo, tem alterado as leis procedimentais, suprimindo outras garantias processuais das partes, ou seja, o que deveria ser uma garantia dos cidadãos (qualquer do povo) contra o Estado, vem sendo um subterfúgio deste para com aqueles.

2 BRÊTAS, Ronaldo. As reformas do Código de Processo Civil e o modelo constitucional do processo. In: BRÊTAS, Ronaldo; NEPOMUCENO, Luciana (Org.). Processo civil reformado. 2. ed. Belo Horizonte: Del Rey, 2009. v. 1. p. 457-496. p. 460.

3 BARROS, Flaviane de Magalhães. (Re)forma do processo penal: comentários críticos dos artigos modificados pelas leis n. 11.690/08 e n. 11.719/08. Belo Horizonte: Del Rey, 2008. p. 1-3.

4 Adota-se neste trabalho a diferença entre Diretos Fundamentais e Garantias Fundamentais apresentada por BRÊTAS C. DIAS (2009, p. 466-467), qual seja: entende-se que, Fundamentais são os direitos humanos expressos e arrolados no artigo $5^{\circ}$ da CR/88, enquanto garantias fundamentais são aquelas de índole processuais compreendidas também na Constituição que formam um sistema de proteção àqueles direitos fundamentais, com vistas a garantir sua efetividade. Exemplificando: a propriedade é direito fundamental (inciso XXII do art. $5^{\circ}$ ), já o devido processo legal é a garantia fundamental (inciso LVI do art. $5^{\circ}$ ) que permite a proteção daquele; a presunção de inocência é direito fundamental (inciso LVII do art. $5^{\circ}$ ), enquanto o Habeas Corpus (inciso LXVIII do art. $5^{\circ}$ ) é uma das garantias apta a lhe proteger. Daí, explica o autor, a Constituição referiu-se em Direitos $\underline{e}$ Garantias Fundamentais. 
Diante dessas razões, este trabalho tem o escopo de analisar, à luz do devido processo legal, o princípio da razoável duração do processo e os meios que garantam sua célere tramitação e a efetividade processual - que muito se associa ao princípio em questão.

Para tanto, o presente inicia-se com uma reconstrução do instituto do devido processo legal a partir do Estado Democrático de Direito, a fim de compreendê-lo adequadamente com o paradigma jurídico-constitucional brasileiro.

Em seguida, serão analisadas, em linhas breves ${ }^{5}$, algumas teorias da efetividade processual e o fator "Tempo" na principiologia constitucional do processo, perquirindo se tais teorias se preocupam com a efetividade processual e da atividade da prestação jurisdicional, ou com os resultados (eficiência) dela.

Nessa perspectiva de esclarecimento dos problemas postos, será apresentada uma contradita à tradicional compreensão de quais fatores determinam a razoável duração do processo, esclarecendo qual a determinante-variável para o "tempo do processo" (procedimento).

Enfim, serão abordadas as implicações trazidas às diferentes funções estatais pelo princípio ora estudado, trabalhando também algumas das inovações sugeridas pelo anteprojeto do novo Código de Processo Civil.

\section{0 devido processo legal: uma reconstrução à luz do estado democrático de direito}

"Ninguém será privado da liberdade nem de seus bens sem o devido processo legal”: é o que dispõe o artigo $5^{\circ}$, inciso LIV, da Constituição da República de 1988. Todavia, a nossa Carta Política não define o que é o Devido

5 Estudo aprofundado foi feito por Joaquim Adelson Cabral de Souza em sua dissertação de mestrado: SOUZA, Joaquim Adelson Cabral de. O discurso da efetividade processual na contemporaneidade brasileira. 2009. 162 f. Dissertação (Mestrado)-Programa de Pós-Graduação em Direito, Pontifícia Universidade Católica de Minas Gerais, Belo Horizonte, 2009. 
Processo Legal. Cabe, portanto, à doutrina conceituar a mencionada garantia constitucional.

Com efeito, entende-se que o instituto do Devido Processo Legal possui um conceito aberto, sendo que sua definição é variável de acordo com o paradigma jurídico e, por conseguinte, com o conceito de processo adotado. Assim, é preciso que se faça uma reconstrução teórica da garantia em questão, a partir dos paradigmas dos Estados Liberal, Social até se chegar ao Estado Democrático de Direito.

Nessa perspectiva, inicia-se a abordagem proposta pelo paradigma do Estado Liberal (Estado de Direito), quando o processo era compreendido como mero meio de resolução de conflito, por influência dos princípios dispositivos e da igualdade formal. O primeiro referia-se ao poder exclusivo das partes de requerer e delimitar o objeto da tutela jurisdicional, o que vinculava o juiz às iniciativas das partes. O segundo, consistente na pressuposição de inexistência de desigualdades entres as partes. Havia no contexto liberal, um protagonismo das partes, vez que o magistrado figurava como um espectador imparcial, sem qualquer interferência, incumbindo-lhe tão somente o respeito às normas processuais consideradas à época, formalidades. Daí falou-se em "Sache der Parteien”, jogo entre as partes ou entre senhores. ${ }^{6}$

Assim, o conceito de devido processo legal atrelava-se e era delimitado pela iniciativa dos envolvidos, não se permitia, portanto, qualquer interferência de terceiros (como o juiz), a ponto de as próprias partes controlarem os prazos processuais e a lei fixar os métodos de apreciação da provas. Logo, o devido processo legal era confundido com devido procedimento legal (série de atos processuais conexos entre si e estabelecidos por lei), determinando apenas o estrito respeito a esta estrutura técnico-normativa.

Lado outro, em virtude do fracasso do liberalismo processual, pois esse sistema privilegiava a parte mais hábil e esperta, causando, dessa forma, dano à

${ }^{6}$ NUNES, Dierle José Coelho. Processo jurisdicional democrático: uma análise crítica das reformas processuais. Curitiba: Juruá, 2008. p. 55-77. 
outra parte, buscou-se uma nova perspectiva teórica a partir da crítica aos problemas degeneratórios do sistema processual liberal. Surge, então, no contexto do paradigma social do direito, o socialismo processual, ${ }^{7}$ quando no Brasil, a partir dos enunciados da teoria do processo como relação jurídica de Oscar Von Bülow, desenvolveram-se estudos acerca dessa teoria, inclusive, sofisticando-a, com destaque para Cândido Rangel Dinamarco. ${ }^{8}$

Para o autor brasileiro supramencionado, o processo teria escopos jurídicos, políticos, sociais e éticos a serem alcançados casuisticamente pelo juiz, o que exige grande interferência deste, considerado como uma "super-parte" ${ }^{9}$ a qual autor e réu estariam subordinados. Dessa forma, verifica-se no eixo do socialismo do processo que o devido processo legal não exige só o estrito cumprimento do procedimento, visto que a ele é acrescido o atributo dos escopos metajurídicos do processo. Para tanto, adota-se a prática de se conferir poderes aos magistrados, em preterição das garantias dos litigantes, com vistas a alcançar tais objetivos, suprimindo os pontos falhos do ordenamento jurídicos, o que resultaria numa pretensa pacificação social. ${ }^{10}$

Considerando que a Constituição de 1988 instituiu o Estado Democrático de Direito, elevando o processo à categoria de direito fundamental, qual seria o conceito de Devido Processo Legal nessa perspectiva constitucional-democrático?

Para responder a essa pergunta, é essencial compreender o processo enquanto garantia constitucional constitutiva de direitos fundamentais, em uma relação de codependência. ${ }^{11}$

7 NUNES, Dierle José Coelho. Processo jurisdicional democrático: uma análise crítica das reformas processuais. Curitiba: Juruá, 2008. p. 77.

8 DINAMARCO, Cândido Rangel. A instrumentalidade do processo. 5. ed. São Paulo: Malheiros, 1996.

9 BARROS, Flaviane de Magalhães. (Re)forma do processo penal: comentários críticos dos artigos modificados pelas leis n. 11.690/08 e n. 11.719/08. Belo Horizonte: Del Rey, 2008. p. $10-16$.

${ }^{10}$ DINAMARCO, Cândido Rangel. A instrumentalidade do processo. 5. ed. São Paulo: Malheiros, 1996.

${ }^{11}$ BARROS, Flaviane de Magalhães. (Re)forma do processo penal: comentários críticos dos artigos modificados pelas leis n. 11.690/08 e n. 11.719/08. Belo Horizonte: Del Rey, 2008. 
Esses direitos fundamentais fazem parte um arcabouço principiológico uníssono (modelo constitucional do processo), esculpido nos conteúdos normativos do artigo $5^{\circ}$ caput e incisos II, XXXIV, XXXV, XXXVII, LIII, LIV, LV e LXXVII; do artigo 93, incisos IX e X; e dos artigos 133 e 134, todos da Constituição Federal.

Destarte, devido processo legal é garantia que se caracteriza pelos princípios da isonomia processual (abrangendo a imparcialidade do Juízo), do contraditório, da ampla defesa (que inclui o direito ao duplo grau de jurisdição e a indispensabilidade da presença do advogado ou defensor público), da inafastabilidade da prestação jurisdicional (acesso à justiça); do juízo natural, do direito-de-ação, da imposição de fundamentação das decisões e da razoável duração do processo e os meios para sua célere tramitação. Essa garantia presta-se a possibilitar a participação dos envolvidos (partes, isto é, aqueles que sofrerão os efeitos do provimento estatal) na construção dialética das decisões (sentença, interlocutórias e acórdão) e na fiscalização incessante - (re) construção - do ordenamento jurídico vigente. ${ }^{12}$

Sendo assim, nesse contexto processual-democrático, não mais faz sentido o tradicional desdobramento do instituto do devido processo legal em sentido substancial - compreendido como instrumento para defender, satisfazer e pleitear direitos (substantive due process) - e em sentido processual (procedural due process), que seriam todas as garantias "formais" (leia: direitos e garantias fundamentais) que compõem o princípio em questão, ${ }^{13}$ porque são exatamente estas que permitem aos cidadãos a "Defesa de Direitos" (em sentido amplo jurídico, enquanto pretensão e resistência) e satisfação dos seus direitos de forma eficiente e democrática. Não há que se falar em devido processo legal substancial sem pensar nos direitos fundamentais que o compõem, pois estes são pressupostos lógico-jurídicos daquele.

Sublinhe-se que essa ideia de devido processo legal em perspectiva democrática, de modo a possibilitar a participação dos envolvidos na construção dos

\footnotetext{
${ }^{12}$ LEAL, Rosemiro Pereira. Teoria processual da decisão jurídica. São Paulo: Landy, 2002.

${ }^{13}$ NERY JÚNIOR, Nelson. Princípios do processo civil na Constituição Federal. 8. ed. rev. ampl. e atual. São Paulo: Revista dos Tribunais, 2004. p. 60-70.
} 
atos decisórios que incidirão sobre a esfera jurídica daqueles, assim como a compreensão do devido processo como instrumento de fiscalização - (re) construção - permanente do ordenamento jurídico, reclama uma interpretação (aplicação) em consonância como o Estado Democrático de Direito, com vistas a estruturar uma procedimentalidade comparticipativa, policêntrica, de aplicação, criação, revisão e desconstituição das leis, isto é, repita-se, de reconstrução do ordenamento.

\subsection{Da interpretação democrática da principiologia do devido processo legal}

A necessidade de se chamar a atenção para a interpretação da principiologia do devido processo, bem como da sua importância, dá-se em decorrência da existência de inúmeras leis anteriores ao constitucionalismo democrático instituído pelo texto de 1988 e pela insistência de um grande número de reconhecidos autores em escrever obras defendendo que a aplicação das leis se dê pela clarividência, pelo saber solitário e magnânimo dos magistrados, ou seja, pelo solipsismo.

Em razão disso, o que se propõe é fazer apontamentos acerca dos princípios do contraditório, da ampla defesa (que inclui o direito ao duplo grau de jurisdição e a indispensabilidade da presença do advogado ou defensor público), da isonomia processual, da inafastabilidade da prestação jurisdicional (acesso à justiça); do juízo natural, do direito-de-ação, da imposição de fundamentação das decisões e da razoável duração do processo e dos meios para sua célere tramitação, a fim de conceituar melhor o instituto do devido processo legal, teorizando-o ao máximo e destacando para a necessidade de compreendê-lo adequadamente no marco Constitucional-Democrático.

A começar pelo contraditório, que, na perspectiva ora estudada, não mais pode ser compreendido apenas como bilateralidade de audiência, assentado no binômio ciência e participação, cuja origem é a expressão latina "audita altera pars", nem como o dizer e o contradizer acerca dos pontos controvertidos da demanda, o que pode ser mais bem denominado de "pseudo-contraditório"; mas sim, enquanto garantia de influenciar ativamente e de forma efetiva na construção das decisões 
(sentença, acórdão ou interlocutórias). Assim são as lições de Aroldo Plínio Gonçalves:

O contraditório não é o "dizer" e o "contradizer" sobre matéria controvertida, não é a discussão que se trava no processo sobre a relação de direto material, não é a polêmica que desenvolve em torno dos interesses divergentes sobre o conteúdo do ato final. Essa é a sua matéria, o seu conteúdo possível. $^{14}$

Nesse norte, por consequência dessa moderna compreensão de contraditório significando direito a influenciar o magistrado na construção do provimento, agrega-se ao princípio em questão a garantia de não surpresa, em vista de sua correlação com a fundamentação das decisões. Logo, fica defeso ao juiz motivar suas decisões com argumentos não suscitados pela partes, o que impõe àquele o dever de provocar o debate acerca de todas as questões relevantes para a solução do caso, inclusive as matérias de conhecimento oficioso, conforme preceitos da legislação estrangeira - art. 16 do Novo Código de Processo Civil da França; $\$ 139$ da ZPO alemã; art. 3, item 3, do Código de Processo Civil de Portugal. Em razão disso, o contraditório vem sendo concebido como garantia de influência e não surpresa. ${ }^{15}$ Compreensão essa, sublinhe-se, foi abarcada pelo anteprojeto do novo Código de Processo Civil brasileiro - Projeto de Lei do Senado 166/2010 - (artigos $10^{16}$ e 110 $\S$ único $\left.{ }^{17}\right)$.

Nessa perspectiva, ampliando-se as implicações do conteúdo teórico da moderna compreensão do contraditório, e interagindo-as como o conceito de ação,

${ }^{14}$ GONÇALVES, Aroldo Plínio. Técnica processual e teoria do processo. Rio de Janeiro: Aide, 1992. p. 127.

${ }^{15}$ NUNES, Dierle José Coelho. Processo jurisdicional democrático: uma análise crítica das reformas processuais. Curitiba: Juruá, 2008. p. 224-239.

${ }^{16}$ Art. 10. O juiz não pode decidir, em grau algum de jurisdição, com base em fundamento a respeito do qual não se tenha dado às partes oportunidade de se manifestar, ainda que se trate de matéria sobre a qual tenha que decidir de ofício.

${ }^{17}$ Art. 110. O juiz decidirá a lide nos limites propostos pelas partes, sendo-lhe vedado conhecer de questões não suscitadas a cujo respeito a lei exige a iniciativa da parte.

Parágrafo único. As partes deverão ser previamente ouvidas a respeito das matérias de que deve o juiz conhecer de ofício. 
ou melhor, a revisão deste feita por Fazzalari ${ }^{18}$, é possível reconstruir o conceito de ampla defesa - agora vista como ampla argumentação ${ }^{19}$-, o que permite rechaçar é a antiga concepção pandectista de ampla defesa como paralelo ao direito de ação, sendo este garantia do autor, e aquela do réu. Isso porque a partir da relação do contraditório com a ampla defesa, esta pressupõe possibilidade ampla de deduzir alegações, mas assegura também a participação nos atos de produção de provas. Com isso, garante-se a participação em todos os atos referentes à construção dos elementos probatórios. A defesa, em direito, pressupõe oportunidade de ampla argumentação e produção de provas. Dito de forma simples, ampla defesa, como ampla argumentação, é o direito tanto do autor quanto do réu, de alegar e provar o que foi alegado. A propósito merece transcrição o seguinte magistério:

A ampla argumentação como garantia das partes, e não como direito subjetivo de "uma" parte, compreende a necessidade de se garantir o tempo do processo para que o esforço reconstrutivo dos argumentos do discurso dialético das partes possa ser apropriado, de modo que todas as possibilidades de argumentação sejam perquiridas. Como salientar Günther, na defesa de uma teoria da argumentação, deve-se pretender a reconstrução da situação por meio de sua descrição completa para que se garanta a argumentação e aplicação das diversas normas prima facie aplicáveis. Na perspectiva do processo jurisdicional, da ampla defesa decorre o direito à prova, à assistência de um advogado, à necessidade de se garantir que as partes possam ter o tempo processual para reconstruir o caso concreto e discutir quais as normas prima facie aplicáveis são adequadas ao caso concreto. ${ }^{20}$

Assim sendo, a fundamentação das decisões judiciais, na perspectiva do processo democrático, há de ser egressa de um espaço procedimental de proble-

${ }^{18}$ FAZZALARI, Elio. Instituições de direito processual. Tradução de Elaine Nassif. Campinas: Bookseller, 2006. Ver também GONÇALVES, Aroldo Plínio. Técnica processual e teoria do processo. Rio de Janeiro: Aide, 1992.

${ }^{19}$ BARROS, Flaviane de Magalhães; CARVALHO, Marius Fernando Cunha de; GUIMARÃES, Natália Chernicharo. O princípio da ampla defesa: uma reconstrução a partir do paradigma do estado democrático de direito. Provocações, Sete Lagoas, MG, n. 2, p. 35-51, jan./dez. 2006.

${ }^{20}$ BARROS, Flaviane de Magalhães. (Re)forma do processo penal: comentários críticos dos artigos modificados pelas leis n. 11.690/08 e n. 11.719/08. Belo Horizonte: Del Rey, 2008. p. 20. 
matização de todas as alegações e argumentos jurídicos relevantes para a dedução de qual a norma, entre as prima facie aplicáveis, é adequada ao caso, ${ }^{21}$ de modo a possibilitar a construção dialética do ato decisório. Isso requer a compreensão do contraditório como influência e como não surpresa, ${ }^{22}$ e da ampla defesa como ampla argumentação, ${ }^{23}$ haja vista que os fundamentos das decisões judiciais decorrem do contraditório e da ampla defesa; porquanto serão construídos pelas alegações das partes - "conteúdo do contraditório" 24 - respaldados no ordenamento jurídico vigente (regras e princípios), apresentados e demonstrados (afirmados) pelos elementos probatórios constantes nos autos, o que se faz em atenção à ampla defesa.

Quanto à isonomia processual, destacam-se os ensinamentos da teoria neoinstitucionalista do processo que preconiza que esta é formada não só pela igualdade das partes perante a lei (isotopia), pois é composta, ainda, pelos aspectos isomênicos (igualdade para interpretar a lei) e isocríticos (igualdade para destruir ou recriar leis), ${ }^{25}$ o que muito contribui para a estruturação de uma procedimentalidade de comparticipação e problematização, com vistas à fiscalização das decisões e à (re)construção do ordenamento jurídico pelos legitimados ao processo.

${ }^{21}$ GÜNTHER, Klaus. The sense of appropriateness: application discourses in morality and law. New York: State University of New York, 1993

GÜNTHER, Klaus. Un concepto normativo de coherencia para uma teoría de la argumentación jurídica. Trad. Juan Velasco Arroyo. Doxa: Cuaderno de Filosofia del Derecho, Alicante, n. 17-18, p. 271-302, 1995.

${ }^{22}$ NUNES, Dierle José Coelho. Processo jurisdicional democrático: uma análise crítica das reformas processuais. Curitiba: Juruá, 2008. p. 224-239.

${ }^{23}$ BARROS, Flaviane de Magalhães; CARVALHO, Marius Fernando Cunha de; GUIMARÃES, Natália Chernicharo. O princípio da ampla defesa: uma reconstrução a partir do paradigma do estado democrático de direito. Provocações, Sete Lagoas, MG, n. 2, p. 35-51, jan./dez. 2006.

${ }^{24} \mathrm{Na}$ perspectiva aqui estudada, o contraditório é garantia daqueles que sofrerão os efeitos do provimento de influenciar de forma efetiva e ativa o magistrado na construção do ato decisório (provimento). A partir disso, conteúdo do contraditório são as alegações e os argumentos aduzidos no espaço-tempo procedimental atinentes às questões discutidas no iter procedimental. Cf. GONÇALVES, Aroldo Plínio. Técnica processual e teoria do processo. Rio de Janeiro: Aide, 1992. p. 127.

${ }^{25}$ LEAL, Rosemiro Pereira. Teoria processual da decisão jurídica. São Paulo: Landy, 2002. p. 109. 
Percebe-se, portanto, que o princípio da imparcialidade do Juízo é decorrente da isonomia processual, eis que aquele não mais se refere ao afastamento do total das pré-compreensões do magistrado, ante a sua impossibilidade ${ }^{26}$ mas diz respeito a garantir às partes tratamento processual igualitário, ou seja, a imparcialidade pressupõe assegurar aos litigantes todos os demais direitos fundamentais caracterizadores do Processo (contraditório, ampla defesa e fundamentação das decisões), nas mesmas condições de espaço-tempo.

Passando a análise do princípio da inafastabilidade da prestação jurisdicional (acesso à justiça), que é, sem sombra de dúvida, direito fundamenta ${ }^{27}$ de apreciação do mérito da causa - lide carnelutiana - levada a juízo (res in judicium deducta), porque o texto constitucional vigente afirma que "[...] a lei não excluirá da apreciação do Poder Judiciário lesão ou ameaça a direito” (art. $5^{\circ}$, inciso, xxxv). É isso que Vicente de Maciel de Paula Junior destaca, propondo uma revisitação às condições da ação:

A não apreciação do mérito por imposição de condicionantes da ação gera um obstáculo de acesso à Justiça que não está previsto em nosso texto constitucional. O cidadão brasileiro tem direito a uma resposta de mérito da questão posta em juízo. Se há um vício ou defeito processual, ele deve ser sanado, conduzindo-se sempre o processo para o julgamento do mérito. ${ }^{28}$

Explicando melhor o ponto concernente à revisitação das condições da ação, defende o processualista mineiro que, quanto a essas, que são a legitimidade,

${ }^{26}$ Segundo os ensinamentos de Gadamer toda compreensão pressupõe pré-compreensões e preconceitos: "não existe compreensão que seja livre de todo preconceito, por mais que a vontade do nosso conhecimento tenha de estar sempre dirigida, no sentido de escapar ao conjunto de nossos preconceitos" GADAMER, 1997, p. 709 apud RIBEIRO, Fernando José A.; BRAGA, Barbara. A aplicação do direito na perspectiva hermenêutica de HansGeorg Gadamer. Revista da Faculdade Mineira de Direito (PUCMG), Belo Horizonte, v. 11, p. 121-143, 2008.

${ }^{27}$ BRÊTAS, Ronaldo. Exame técnico e sistemático do Código de Processo Civil reformado. In: BRÊTAS, Ronaldo; NEPOMUCENO, Luciana (Org.). Processo civil reformado. 2. ed. Belo Horizonte: Del Rey, 2009. v. 1. p. 407-456.

${ }^{28}$ MACIEL JUNIOR, V. P. Estrutura e interpretação do direito processual civil brasileiro a partir da Constituição Federal de 88. In: MACHADO, Felipe Daniel Amorim; OLIVEIRA, Marcelo Andrade Cattoni de (Org.). Constituição e processo: a contribuição do processo ao constitucionalismo democrático. 2008. p. 292-311. 
a possibilidade jurídica do pedido e o interesse processual de agir, não poderiam impedir a apreciação do mérito do caso levado a juízo, seja porque a condição da ação refira-se, em verdade, ao mérito (legitimidade e possibilidade jurídica do pedido), seja porque há que se superar a retrógrada compressão (interesse processual de agir).

Especificamente, defende que a legitimidade de agir diz respeito ao mérito, já que envolve produção de provas e, já advertia Fazzalari, ${ }^{29}$ que a legitimidade de agir será aferida na sentença, uma vez que a parte é aquela pessoa (física ou jurídica) que sofrerá os efeitos do provimento final; é quem atuou no procedimento em contraditório em simétrica paridade.

Quanto à possibilidade jurídica, jamais poderia ser considerada com condição da ação; porquanto, como muito bem ressaltado por Alexandre Fretas Câmara, o pedido encontra-se atrelado à sua causa de pedir. $\mathrm{O}$ pedido é decorrente lógico-jurídico da sua causa de pedir próxima, razão pela qual não se deve falar em possibilidade jurídica do pedido, pois o pedido não é impossível, mas, sim, a sua causa de pedir. Exemplificando: "A" propõe ação em desfavor de "R" pleiteando o pagamento de uma dívida decorrente de jogo de aposta. Nesse caso, o pedido será a condenação de " $\mathrm{R}$ ” ao pagamento de uma dívida sob a importância de XX, isso não é impossível; todavia, o Código Civil (artigo 814) veda a cobrança de dívida oriunda de jogo de aposta. Veja-se, então, que há impossibilidade da causa de pedir. ${ }^{30}$

A terceira e última das condições da ação, o interesse processual, é dividido em interesse-necessidade e interesse-adequabilidade: quanto ao interesse-necessidade, que se refere à inexistência de forma diversa da jurisdicional para a solução do litígio, realmente se encontra em desuso; o interesse-adequabilidade, por sua vez, diz respeito à adoção do procedimento ou mecanismo processual tecnicamen-

${ }^{29}$ FAZZALARI, Elio. Instituições de direito processual. Tradução de Elaine Nassif. Campinas: Bookseller, 2006.

${ }^{30}$ CÂMARA, Alexandre Freitas. Lições de direito processual civil. 20. ed. rev. e atual. Rio de Janeiro: Lumen Juris, 2010. p. 128-130. 
te adequado. ${ }^{31}$ Esse sim há que ser observado, uma vez que técnica não é formalismo, mas sim a utilização dos melhores meios para se alcançar um fim, além do que, não só a ciência processual, mas qualquer ramo do saber, depende da melhor técnica para sua evolução. No entanto, a lei processual em respeito ao princípio da fungibilidade, é condescendente com a inobservância da melhor técnica.

Maciel Junior ${ }^{32}$ comenta também acerca dos pressupostos processuais que, quando ausentes um ou mais, geram um vício processual convalidável, razão pela qual há que se dar a oportunidade da parte (ou melhor, de seu procurador) de sanar o vício, porém caso este não seja sanado no prazo determinado, não há outra solução, se não a de extinguir o processo sem resolução do mérito por desinteresse.

Já no ponto atinente à Ação, ou melhor, o Direito-de-Ação, cabe destacar que já foram superadas as diversas teorias que tentaram definir esse importantíssimo elemento do Direito Processual, tais como: a teoria imanentista (1840), que preconizava ser o direito material imanente à ação, ou seja, haveria para cada direito material uma ação correspondente; ${ }^{33}$ a teoria da ação como direito autônomo e concreto de WACH (1860-1870), autônomo, uma vez que o direito material não seria pressuposto da ação, mas esta só existiria nos casos em que houvesse sentença favorável ao autor, daí falou-se em direito concreto; ${ }^{34}$ tangente a essa se encontra a teoria de Chiovenda, que concebia a ação como um direito potestativo, isto é,

${ }^{31}$ CÂMARA, Alexandre Freitas. Lições de direito processual civil. 20. ed. rev. e atual. Rio de Janeiro: Lumen Juris, 2010. p. 128-130.

${ }^{32}$ MACIEL JUNIOR, V. P. Estrutura e interpretação do direito processual civil brasileiro a partir da Constituição Federal de 88. In: MACHADO, Felipe Daniel Amorim; OLIVEIRA, Marcelo Andrade Cattoni de (Org.). Constituição e processo: a contribuição do processo ao constitucionalismo democrático. [S.l.: s.n.], 2008. p. 292-311. p. 301-302.

${ }^{33}$ BARROS, Flaviane de Magalhães; CARVALHO, Marius Fernando Cunha de; GUIMARÃES, Natália Chernicharo. O princípio da ampla defesa: uma reconstrução a partir do paradigma do estado democrático de direito. Provocações, Sete Lagoas, MG, n. 2, p. 35-51, jan./dez. 2006. Em estudo sobre o ciclo histórico da Ação, Rosemiro Pereira Leal conclui: "Assim, para essa escola, o direito material (bem da vida jurídica) era imanente à ação para exercê-lo, o que queria dizer que ação e direito material surgiam de modo geminado, não sendo possível separá-los” Cf. LEAL, Rosemiro Pereira. Teoria geral do processo: primeiros estudos. 8. ed. rev. e atual. São Paulo: Forense, 2009. p. 130.

${ }^{34}$ LEAL, Rosemiro Pereira. Teoria geral do processo: primeiros estudos. 8. ed. rev. e atual. São Paulo: Forense, 2009. p. 130-131. 
seria a ação um direito autônomo, ou melhor, nesse caso, um poder pelo qual se pretenderia fazer valer em juízo um direito material contra outrem que nada poderia fazer. ${ }^{35}$ Para Degenkolb e Plosz (1877), a ação deve ser entendida como direito público, autônomo e abstrato, o que pode ser entendido, segundo Rosemiro Pereira Leal, ${ }^{36}$ como direito incondicionado de movimentar à jurisdicional. Modernamente, é certo que a ação (direito-de-ação) é direito fundamental de movimentar à jurisdição (diferente da judicatura dos instrumentalistas - aqui entendida como a atividade discricionária do juiz com vistas a atingir os escopos metajurídicos do processo, a fim de suprir as falhas do ordenamento jurídico) regida, por sua vez, pelo devido processo legal (modelo constitucional do processo). Assim são as lições de Ronaldo Brêtas:

Inspirando-nos na doutrina de Couture e levando em conta o princípio da supremacia da Constituição, entendemos que, em sentido jurídico amplo, ação, espécie do gênero direito de petição, é direito constitucionalmente assegurado a qualquer pessoa (natural ou jurídica, de direito público ou de direito privado), exercido contra o Estado, consistindo em lhe exigir seja prestada a função jurisdicional, tendo por base a instauração de um processo legal e previamente organizado, segundo o modelo constitucional, no qual se postulará decisão sobre uma pretensão de direito material (Constituição Federal, art. $5^{\circ}$ inciso XXXIV, alínea a, e incisos XXXV, LIV e LV) (grifo do autor). ${ }^{37}$

A razoável duração do processo e os meios que garantem a sua célere tramitação, repita-se, serão trabalhadas em um tópico próprio por fazerem parte do objeto deste estudo. Antes, porém, é preciso trabalhar temas conexos a esse direito fundamental, dentre os quais, o tempo e a efetividade do processo, o que se passa a fazer no próximo capítulo.

${ }^{35}$ CINTRA, Antônio Carlos de Araújo; GRINOVER, Ada Pellegrini; DINAMARCO, Cândido R. Teoria geral do processo. 24. ed. rev. e atual. São Paulo: Malheiros, 2008. p. 269.

${ }^{36}$ LEAL, Rosemiro Pereira. Teoria geral do processo: primeiros estudos. 8. ed. rev. e atual. São Paulo: Forense, 2009. p. 131-132.

${ }^{37}$ BRÊTAS, Ronaldo. As reformas do Código de Processo Civil e o modelo constitucional do processo. In: BRÊTAS, Ronaldo; NEPOMUCENO, Luciana (Org.). Processo civil reformado. 2. ed. Belo Horizonte: Del Rey, 2009. v. 1. p. 457-496. p. 446. 


\section{Tempo e efetividade processual na principiologia do processo}

Muito se tem escrito acerca da efetividade processual, ligando-a ao fator “Tempo", isto é, o "Tempo" é considerado como o grande causador da inefetividade do processo. Entretanto, se o tempo é um fator natural que simplesmente flui sem força e de forma uniforme, independentemente dos atos (ações e omissões) humanos, pode este ser considerado "fator de corrosão" de direitos e, portanto, causador da inefetividade processual?

Fernando Horta Tavares, em estudo acerca do princípio da razoável duração do processo, apresenta a seguinte resposta para o questionamento acima exposto:

[...] não é o tempo que corrói, por que o "tempo apenas passa"; em si, o tempo nada pode corroer; já que flui em marcha: não tem força ou ação para corroer. O Tempo, por si, "não causa malefício algum": alguém é quem pode causar danos a outrem, isto é, um sujeito prejudicar a outro, propositadamente ou não. Logo, "o tempo não pode ser inimigo, por que só passa, é um acontecimento natural." ${ }^{38}$

Em seguida, conclui:

Responsabilizar o tempo por danos soa como uma evasiva mítica, sendo inevitável questionar-se sobre o quê ou quem se esconde, ou o quê se quer proteger ou poupar para justificar a inaplicabilidade do denominado "direito à tempestividade da resposta jurisdicional” $[\ldots] .{ }^{39}$

Destarte, o tempo não é mesmo inimigo dos homens nem do Direito, por ser igual para todos, além de ser um acontecimento natural e inevitável. O homem é quem não consegue por diversos motivos realizar seus objetivos ou suas obrigações (deveres legais) no tempo almejado ou prescrito em lei.

38 TAVARES, Fernando Horta. Tempo e Processo. In: GALUPPO, Marcelo Campos (Org.). O Brasil que queremos: reflexão sobre o Estado Democrático de Direito. Belo Horizonte: PUCMINAS, 2006. v. 1. p. 585-626.

39 TAVARES, Fernando Horta. Tempo e Processo. In: GALUPPO, Marcelo Campos (Org.). O Brasil que queremos: reflexão sobre o Estado Democrático de Direito. Belo Horizonte: PUCMINAS, 2006. v. 1. p. 585-626. 
Superada a problemática da questão "Tempo", há que se revisitar a partir da principiologia do processo, a efetividade processual, que por sua vez, encontra-se segundo magistério de inúmeros processualistas de renome, arraigada ao fator "Tempo" e a teorias do processo que vão de encontro aos ditames do Estado Democrático de Direito.

Uma das principais lições é a de Marinoni, propondo o que ele próprio denomina de "distribuição do ônus do tempo do processo" como forma de se alcançar a efetividade do processo, haja vista que, com a concessão de tutelas antecipadas - por meio de cognição sumária horizontal ${ }^{40}$-, o réu é quem sofreria os males do "tempo do processo", pois o autor ficaria com a posse do bem da vida pleiteado em juízo até o desfecho final da lide (artigos 273, 461 e 461-A do CPC), o que rompe com a ordem tradicional do sistema.

Por essas razões, destaca-se para a necessidade de se pesquisar sobre diferentes modalidades de proteção jurisdicional com vistas a enunciar procedimentos que permitam a realização do direito material por meio de cognição sumária, a fim de que a prestação jurisdicional possa satisfazer o crédito (bem da vida pretendido) reconhecido em juízo:

A questão da efetividade do processo, pois, obrigou o processualista a pensar sobre tutelas jurisdicionais diferenciadas, isto é, tutelas adequadas às particularidades das situações de direito substancial. Nessa linha, de grande importância é a pesquisa de procedimentos que permitam a realização do direito material mediante cognição sumária, pois não é mais possível a confusão entre justiça e certeza. ${ }^{41}$

${ }^{40}$ Ovídio Araújo Baptista da Silva diferencia a cognição sumária vertical da sumária horizontal: nesta, o juiz aprecia todas as provas e questões suscitadas, porém de forma superficial. Por exemplo, nos casos de decisões liminares: naquela, a apreciação do juiz se limitaria a determinadas questões (matérias) e provas, como, por exemplo, nos casos de mandado de segurança que só é admissível produção de provas por meio documental. Ver: SILVA, Ovídio A. Baptista da. O contraditório nas ações sumárias. Revista Jurídica: Órgão Nacional de Doutrina, Jurisprudência, Legislação e Crítica Judiciária, Porto Alegre, v. 49, n. 287, p. 5-29, set. 2001.

${ }^{41}$ MARINONI, Luiz Guilherme. Efetividade do processo e tutela de urgência. Porto Alegre: S. A. Fabris, 1994. p. 37-38. 
Doutrina tangente à de Marinoni é de Ovídio Baptista da Silva, que aponta o procedimento ordinário, especialmente sua sistemática recursal, como um dos grandes fatores causadores da inefetividade processual, propondo como solução para resolver esse problema, o que ele chama de "regaste das ações sumárias". ${ }^{42}$

Acerca dessas proposições, importa mencionar, que no marco teórico aqui estudado, jamais poderia cogitar a sumarização da cognição por imposição do devido processo legal, especificamente em respeito à ampla defesa, que garante amplitude de alegação e de provar o que foi alegado, com todos os seus recursos (direito ao advogado e utilização do sistema recursal estabelecido em lei) e em espaço-tempo procedimental hábil.

Pode-se falar, sim, em "sumarização da técnica procedimental”, prática já adotada pelo legislador brasileiro, pois com as intermináveis reformas processuais introduzidas no Código de Processo Civil de 1973, criou-se o sincretismo processual (lei 11.232/05) e o instituto da Tutela Antecipada - Lei 8.952/94 - ${ }^{43}$, só para citar algumas das novidades introduzidas após 1973. Mas a inefetividade, tanto processual quanto da função jurisdicional continua segundo as aludidas correntes doutrinárias. Vê-se que o problema não é o procedimento ordinário e seu sistema recursal.

Pensamento que também merece ser citado é o de Cândido Rangel Dinamarco, pois se alinha à ideia de socialização do processo. Segundo esse autor, para se chegar à efetividade do processo, é preciso permitir uma maior interferência do juiz, admitindo-se, inclusive, que se afaste (desrespeite, suprima) a Legalidade, com vistas a alcançar os escopos metajurídicos do processo como meio de pacificação social:

Processo efetivo não é apenas o que rigorosamente atue a vontade concreta do direito, mas o que seja capaz de cumprir os escopos do sistema [...] O processo que chegue ao ideal

${ }^{42}$ SILVA, Ovídio A. Baptista da. O contraditório nas ações sumárias. Revista Jurídica: Órgão Nacional de Doutrina, Jurisprudência, Legislação e Crítica Judiciária, Porto Alegre, v. 49, n. 287, p. 5-29, set. 2001.

${ }^{43}$ TAVARES, Fernando Horta. Tempo e Processo. In: GALUPPO, Marcelo Campos (Org.). O Brasil que queremos: reflexão sobre o Estado Democrático de Direito. Belo Horizonte: PUCMINAS, 2006. v. 1. p. 585-626. 
de segurança jurídica com razoável celeridade, eliminando o conflito, é eficaz e legitimado pela utilidade social, ainda que falho do ponto-de-vista jurídico. ${ }^{44}$

Paradoxalmente, os adeptos da teoria do processo como relação jurídica preconizam ser necessário conferir "poderes" aos magistrados, para que eles possam suprir as lacunas do ordenamento jurídico e realizar os escopos metajurídicos do processo, negando a todo custo, a fiscalização - (re) construção - incessante das leis por qualquer do povo (soberania popular), que são destinatários e coautores do ordenamento jurídico. ${ }^{45}$ Ora, o processo não se presta apenas para a "Defesa de Direitos”, mas também para a fiscalização do ordenamento jurídico e das decisões judiciais. $^{46}$

O que se vê é que essas teorias - que defendem que a efetividade do processo consiste em satisfazer o crédito (bem da vida jurídico) pretendido e reconhecido em juízo - não se preocupam com a efetividade (capacidade de fazer a coisa certa) do processo nem da jurisdição, visto que esta atua e se legitima por aquele (processo). Ou seja, a efetividade tanto do processo como da jurisdição, reclama a observância aos direitos fundamentais que constituem a garantia do devido processo legal. A grande preocupação das citadas teorias é com os resultados (eficiência) da jurisdição. Contudo, não atacam o problema causador dessa ineficiência jurisdicional, embora o reconheçam, a saber: a falta de estrutura organizacional e tecnicamente qualificada.

Além do mais, não é possível falar em efetividade, seja do processo, seja da jurisdição, sem a observância do ordenamento jurídico vigente, sobretudo do texto Constitucional, tendo em vista que é ele que disciplina a atuação da jurisdição que é regida, por sua vez, pelo processo, que é efetivo em bases democráticas, quando se assegura aos cidadãos os direitos fundamentais formadores do arcabouço principiológico discursivo do devido processo legal, notadamente contraditório, ampla

\footnotetext{
${ }^{44}$ DINAMARCO, Cândido Rangel. A instrumentalidade do processo. 5. ed. São Paulo: Malheiros, 1996. p. 325.

${ }^{45}$ HABERMAS, Jürgen. Direito e democracia: entre facticidade e validade. Rio de Janeiro: Tempo Brasileiro, 1997. (Biblioteca Tempo Universitário, 101-102).

${ }^{46}$ LEAL, Rosemiro Pereira. Teoria processual da decisão jurídica. São Paulo: Landy, 2002.
} 
defesa, fundamentação das decisões e isonomia processual, neste já incluída a imparcialidade do juízo, o que implicará ganho de legitimidade da decisão jurídica, conforme muito bem explicitado por Souza ${ }^{47}$, com base em Rosemiro Leal. ${ }^{48}$

Nessa perspectiva de esclarecimento e de demonstração das oporias teóricas relativas à razoável duração do processo, mister esclarecer qual ou quais os fator(es) que determina(m), ou deveria(m) determinar a "duração do processo", tendo em vista que, mais uma vez, a teoria informadora desta (duração do processo) mostra-se inconsistente em face da compreensão de devido processo legal no marco do Estado Democrático de Direito.

Para tanto, é preciso, primeiramente, contraditar a teoria que informa, equivocadamente, quais são os fatores determinantes da "duração do processo", para no final, demonstrar qual o fator influi para o maior ou menor tempo de deslinde da lide. Essa será a proposta do capítulo seguinte.

\section{A produção de prova como variável determinante da duração do procedimento: uma contradita à dicção tradicional}

A doutrina tradicional aponta como sendo três os fatores determinantes do "tempo do processo", quais sejam: a atuação dos procuradores das partes; a atuação do Poder Judiciário; e a complexidade da causa ${ }^{49}$ Contudo, à luz da principiologia constitucional do processo (devido processo legal), conclui-se não serem esses os fatores determinantes da duração do processo.

${ }^{47}$ SOUZA, Joaquim Adelson Cabral de. Odiscurso daefetividade processual na contemporaneidade brasileira. 2009. 162 f. Dissertação (Mestrado)-Programa de Pós-Graduação em Direito, Pontifícia Universidade Católica de Minas Gerais, Belo Horizonte, 2009.

${ }^{48}$ LEAL, Rosemiro Pereira. Teoria geral do processo: primeiros estudos. 8. ed. rev. e atual. São Paulo: Forense, 2009.

LEAL, Rosemiro Pereira. Teoria processual da decisão jurídica. São Paulo: Landy, 2002.

${ }^{49}$ MELO, Gustavo de Medeiros. A tutela adequada na reforma constitucional de 2004. Revista de Processo, São Paulo, v. 30, n. 124, p. 76-110, jun. 2005. Ver também: TUCCI, José Rogério Cruz e. Tempo e processo: uma análise empírica das repercussões do tempo na fenomenologia processual (civil e penal). São Paulo: Revista dos Tribunais, 1997. 
Quem afirma que a atuação das partes e dos seus procuradores é determinante para a "duração do processo" esquece dos institutos da decadência, da prescrição e, principalmente, da preclusão, que são infalíveis para as partes e seus procuradores; apesar de inexistirem para os magistrados, o Ministério Público e os serventuários do judiciário.

O primeiro é “a perda do prazo para estar em juízo a pleitear direitos"; o segundo é "a perda do prazo de obter ato ou sentença reconhecedora de direitos em procedimento instaurado"; ${ }^{50}$ o terceiro e último é a perda da faculdade de praticar ato processual.

Com efeito, percebe-se que há uma ligação entre o tempo e o exercício de direitos, sendo que a inércia do interessado traz consequências jurídicas. Quase sempre, especialmente depois de instaurado o procedimento, a inobservância dos prazos pelas partes implica prejuízos a elas.

Dessa forma, não se pode afirmar que há abuso de direito de defesa quando as partes utilizam os mecanismos processuais - recursos, contestação, exceções, reconvenção e etc. - postos à sua disposição dentro do espaço-tempo procedimental. Só haverá abusos, se praticado fora do prazo determinado pela lei, o que, reitera-se, para as partes é praticamente impossível, vez que a preclusão é infalível. Ou seja, não se protela o que está dentro do tempo e o que estiver fora é atingido pela prescrição, preclusão e decadência..$^{51}$

Além do mais, embora grande parte da doutrina e dos operadores do direito culpe o sistema recursal brasileiro pela demora da prestação jurisdicional, inexiste estudo empírico-científico ou analítico-comparativo com o direito comparado comprovando essa afirmação. Trata-se, na verdade, de mais um subterfúgio para não implementar um sistema judiciário que atenda aos anseios da sociedade moderna e, ao mesmo tempo, respeite à Constituição de 1988.

${ }^{50}$ LEAL, Rosemiro Pereira. Teoria geral do processo: primeiros estudos. 8. ed. rev. e atual. São Paulo: Forense, 2009. p. 184.

${ }^{51}$ LEAL, Rosemiro Pereira. Teoria geral do processo: primeiros estudos. 8. ed. rev. e atual. São Paulo: Forense, 2009. p. 166-171 
De resto, destaca-se que a atuação dos procuradores das partes deve-se pautar pelo princípio da lealdade processual. Princípio este desvinculado das virtudes intrínsecas das partes ou de seus procuradores, longe dos comportamentos moralmente estabelecidos pela sociedade, e próximo das condutas exigidas e disponibilizadas pela LEI - espaço-tempo procedimental discursivo de construção das decisões. $^{52}$

Contudo, caso haja qualquer comportamento que se coadune ao exigido por esse princípio, ${ }^{53}$ o próprio Código de Processo Civil brasileiro (arts. 17 e 18) estabelece meios para punir, tanto as partes quanto os seus procuradores. E, para reprimir os comportamentos desvirtuantes desses últimos, há também mecanismos prescritos no Código de Ética da OAB.

No tocante à atuação do Poder Judiciário, ele não determina a “duração do processo", pois o princípio da reserva legal é que impõe à atuação daquele. É, portanto, o direito fundamental da razoável duração do processo que determina a atuação do judiciário. Ora, o Brasil é um Estado de Direito Democrático que adotou o sistema da civil law. Este, por sua vez, é estruturado pela Lei (reserva legal). Cabe, assim, aos magistrados e serventuários a aplicação cogente desta, cumprindo-se, então, os atos que lhes incumbe nos prazos processuais prescritos (artigo 189, I e II do CPC).$^{54}$ Eis que o princípio da legalidade é referente lógico-jurídico para qualquer atuação da esfera estatal, principalmente quando se trata de direitos fundamentais.

${ }^{52}$ LEAL, Rosemiro Pereira. Teoria geral do processo: primeiros estudos. 8. ed. rev. e atual. São Paulo: Forense, 2009. p. 113-114.

${ }^{53}$ Além do princípio da lealdade, Ronaldo Brêtas, em obra destaque sobre o tema, arrola como princípios repressivos à fraude processual os princípios do dever de veracidade, dever de prontidão e de probidade. O primeiro prescrito no inciso I do artigo 14 do CPC, impõe que se exibam os fatos conforme a verdade. O segundo determina a não protelação do andamento processual, pois exige que as partes pratiquem seus atos processuais tão logo o possam fazer, não podendo, por exemplo, se esquivar do dever legal de apresentar provas que as detenha. $\mathrm{O}$ último exige que o litigante observe as regras atinentes à moral, sem ardis, sem fraude e trapaça. Cf. BRÊTAS, Ronaldo. Fraude no processo civil. 3. ed. Belo Horizonte: Del Rey, 2001. p. 86-94.

${ }^{54}$ Art. 189. O juiz proferirá:

I - os despachos de expediente, no prazo de 2 (dois) dias;

II - as decisões, no prazo de 10 (dez) dias. 
Argumenta-se que nem sempre o lapso temporal prescrito pela lei para a realização de algum ato - prazo -, seja ele prescritivo, decadencial, ou preclusivo é razoável. ${ }^{55}$ Porém não deve se discutir no espaço-tempo procedimental-judicial a razoabilidade ou não do prazo estabelecido pela norma, tanto as partes quanto os agentes públicos (magistrados ou serventuários) devem cumprir a lei, sob a consequência de preclusão temporal para os primeiros e responsabilidade civil para os últimos. ${ }^{56}$

Por fim, considera-se também a "complexidade da causa", um dos fatores de aferição do "tempo do processo", dividindo-a em complexidade de fato e de direito. Todavia, esse ponto precisa passar por um maior esclarecimento. O correto é falar em complexidade em demonstrar (afirmar) os argumentos fático-jurídicos aduzidos pelas partes, o que se faz pela produção de provas. A prova é o elemento que apresenta e demonstra - afirma, ratifica - os argumentos fático-jurídicos aduzidos pelas partes, por meios intelectivos autorizados pela lei. ${ }^{57}$ Fático-jurídicos, porque a prova se presta à confirmação da situação fática reconstruída exaustivamente em contraditório pelos envolvidos, que, por conseguinte, referem-se aos argumentos jurídicos (alegações de preliminares ou de mérito) articulados com o intuito de se deduzir qual a norma, entre as prima facie aplicáveis, é adequada ao caso. ${ }^{58}$

${ }^{55}$ MELO, Gustavo de Medeiros. A tutela adequada na reforma constitucional de 2004. Revista de Processo, São Paulo, v. 30, n. 124, p. 76-110, jun. 2005.

${ }^{56}$ BRÊTAS, Ronaldo. Responsabilidade do estado pela função jurisdicional. Belo Horizonte: Del Rey, 2004. p. 174-203. Ressalta-se que o autor defende a tese de responsabilidade do Estado não só por omissão (demora da prestação jurisdicional), mas, também, por erro e por ato pessoal do juiz. Nessa última hipótese, o prejudicado poderia requerer em juízo a responsabilização do Estado ou do juiz. Destaca-se, ainda, para o ponto em que o autor afirma ser possível pleitear indenização por atuação de juiz obtuso, conceituando este como aquele que age com imperícia ou incúria.

${ }^{57}$ LEAL, Rosemiro Pereira. Teoria geral do processo: primeiros estudos. 8. ed. rev. e atual. São Paulo: Forense, 2009. p. 196-197.

${ }^{58}$ GÜNTHER, Klaus. The sense of appropriateness: application discourses in morality and law. New York: State University of New York, 1993

GÜNTHER, Klaus. Un concepto normativo de coherencia para uma teoría de la argumentación jurídica. Trad. Juan Velasco Arroyo. Doxa: Cuaderno de Filosofia del Derecho, Alicante, n. 17-18, p. 271-302, 1995. 
Daí, fala-se na inexistência do desdobramento de questões de direito e de fato. ${ }^{59}$

Acontece que há três diferentes meios (procedimentos) intelectivos de demonstração dos fatos e argumentos deduzidos: produção de prova documental, testemunhal e pericial. Cada um com sua especificidade e grau de complexidade.

Observe o procedimento de produção de prova documental, aqui entendida como a confirmação do acontecimento ou existência de um fato, podendo ser escrita ou gravada (fotografias, filmes gravações sonoras, etc.), pública ou particular. A Lei Processual Civil (art. 396) determina que o documento deva instruir a petição inicial (art.283) ou a réplica (art. 326), pelo autor; ou instruir a resposta (art. 297), pelo réu.

Todavia, permite-se às partes a juntada de documentos em momentos diferentes destes, desde que se destine a fazer prova de fatos ocorridos depois dos articulados ou para contrapô-los aos que foram produzidos nos autos (art. 397). De todo modo, em respeito ao contraditório, há que se intimar a outra parte para se manifestar, em 5 dias, acerca do requerimento de juntada de documentos (art. 398). De resto, é possível que o juiz requisite às repartições públicas, em qualquer tempo ou grau de jurisdição, certidões necessárias à prova das alegações das partes e os procedimentos administrativos nas causas em que forem interessados as Pessoas Jurídicas de Direito Privado.

Por outro lado, há também o procedimento de produção de prova oral, consistente no depoimento pessoal, no interrogatório e na oitiva de testemunha. A primeira espécie de prova é o testemunho de uma das partes (autor ou réu) prestado em juízo em audiência de instrução e julgamento; o segundo consiste no testemunho da parte acerca dos fatos da causa, não necessariamente na audiência de instrução e julgamento, pois pode ser feito a qualquer tempo, a requerimento

${ }^{59}$ BARROS, Flaviane de Magalhães; CARVALHO, Marius Fernando Cunha de; GUIMARÃES, Natália Chernicharo. O princípio da ampla defesa: uma reconstrução a partir do paradigma do estado democrático de direito. Provocações, Sete Lagoas, MG, n. 2, p. 35-51, jan./dez. 2006. 
da parte ou ex offício, sem, contudo, ter o condão de gerar confissão, em caso de não comparecimento da parte intimada, como ocorre no depoimento pessoal. ${ }^{60} \mathrm{~A}$ última reside no testemunho em juízo de terceiros (aqueles que não são partes). Quanto aos atos de produção (proposição, admissão e produção propriamente dita), destaca-se que a parte deve indicar o rol de testemunhas (propor a prova) no prazo que o juiz fixará ao designar a data da audiência, depositando em cartório o rol de testemunhas, precisando-lhes o nome, a profissão, a residência e o local de trabalho. Omitindo-se o juiz, o rol deve ser apresentado até 10 (dez) dias antes da audiência, isso quanto se tratar de procedimento ordinário (art. 401). Eis que, em se tratando de procedimento sumário, o rol de testemunha há de ser indicado junto com a petição inicial (art. 276). Na audiência, a parte não só pode como deve contraditar a testemunha em casos de incapacidade, impedimento ou suspeição dela, podendo, inclusive, produzir prova oral ou documental no sentido de comprovar sua alegação (art. $411 \S 1^{\circ}$ ). Em caso de indeferimento da contradita apresentada, há que se interpor agravo na modalidade retida oral (art. $523 \$ 3^{\circ}$ ).

Por último, analisa-se, o procedimento de produção de prova pericial, que consiste em avaliação, exame ou vistoria técnica acerca de algum fato ou objeto relevante para a resolução do mérito. Quanto à procedimentalidade, o juiz nomeará perito, oportunidade em que fixará prazo para a entrega do laudo (resultado da perícia). Entretanto, por um erro legislativo, inexiste um limite temporal máximo ou mínimo para esse ato. Lado outro, é certo que em cinco dias, contados da intimação do despacho de nomeação do perito, as partes hão de indicar assistente técnico e/ou apresentar quesitos (art. 421, incisos I e II). Realizada a perícia no prazo fixado pelo juiz, o expert apresentará o laudo em cartório, pelo menos 20 (vinte) dias antes do da audiência de instrução e julgamento (art. 433). Em seguida, as partes deverão, em 10 (dez) dias, manifestar-se acerca do laudo.

Se se analisar a procedimetalidade desses três meios de provas, é fácil concluir que a produção de prova pericial é a mais complexa e demanda um lapso temporal maior que as provas orais e documentais, e esta, frise-se, a menos complexa e

${ }^{60}$ CÂMARA, Alexandre Freitas. Lições de direito processual civil. 20. ed. rev. e atual. Rio de Janeiro: Lumen Juris, 2010. p. 421-422. 
mais rápida das três, até porque, via de regra, sua produção ocorre simultaneamente com a fase postulatória (petição inicial, resposta e réplica).

A série de atos conexos entre si de produção de prova pericial - nomeação de peritos, indicação de assistentes técnicos e/ou apresentação de quesitos, apresentação do laudo pericial em cartório, manifestação sobre o laudo, audiência para de instrução e julgamento para maiores esclarecimentos - é maior que a de produção oral e documental. A complexidade da causa (lide), portanto, reside nas provas a serem produzidas, ou seja, nos meios intelectivos de demonstração, afirmação dos fatos deduzidos.

Além do que, existem no Código de Processo Civil vigente outros conteúdos normativos que corroboram a tese aqui defendida (que é o procedimento de produção de prova que determina o "tempo do processo"), a saber: o esdrúxulo art. 285-A que autoriza o juiz a indeferir totalmente o pedido do autor, caso já tenha esse mesmo juiz proferido sentença em "causa idêntica", se a demanda versar apenas sobre questões de direito "ou se não houver mais provas" a serem produzidas, dispensando a citação do réu ${ }^{61}$ e o preceito do parágrafo $3^{\circ}$ do art. 515, que prescreve que, nos casos de extinção sem julgamento do mérito (art. 269), o tribunal pode julgar desde logo a lide (mérito - res in judicium deducta), "se a causa versar questão exclusivamente de direito e estiver em condições de imediato julgado" (leia-se: não houver mais prova a ser produzida).

Pelo exposto, infere-se que a razoável duração do processo diz respeito ao procedimento, porque ele estabelece o marco inicial (dies a quo) e o marco final (dies ad quem) para a prática de atos processuais, sendo que o procedimento de produção de provas é o variável-determinante do maior ou menor lapso temporal para o desfecho final da lide (sentença de mérito).

${ }^{61}$ Art. 285-A. Quando a matéria controvertida for unicamente de direito e no juízo já houver sido proferida sentença de total improcedência em outros casos idênticos, poderá dispensar a citação e proferida sentença, reproduzindo-se o teor da anteriormente prolatada. 
Esclarecido mais um ponto relativo à razoável duração do processo, pode-se passar à análise especifica dele, a fim de se cumprirem os desafios propostos por esta pesquisa.

\section{A razoável duração do "processo" e os meios que garantam sua célere tramitação: implicações}

\subsection{Aspectos introdutórios e conceituação}

Preliminarmente, antes de se prosseguir à exposição acerca desse princípio, importa apontar a imprecisão técnico-científica do legislador, porque, no marco processual aqui estudado, o "Processo" é garantia que se define pelos direitos fundamentais do contraditório, ampla defesa, imposição de fundamentação das decisões e isonomia processual, por isso, é “infinito” (permanente), não tendo duração (lapso temporal entre dois eventos). O que possui duração é o "Procedimento", visto que a própria lei determina o seu marco inicial (dies a quo) e marco final (dies ad quem $){ }^{62}$

O mais recente Direito Fundamental de índole processual foi introduzido no rol dos Direitos e Garantias Fundamentais pela Emenda à Constituição no. 45/2004, embora este já houvesse sido inserido no ordenamento jurídico brasileiro, pelo caput do artigo $8^{\circ}$ da Convenção Americana de Direitos Humanos - Pacto de São José da Costa Rica -, desde 1992.

A positivação desse Direito Fundamental foi motivada pela necessidade de se concretizar a tão desejada reforma do judiciário, em decorrência do insuportável problema da morosidade judicial, que passa um enorme descrédito ao Judiciário brasileiro, tendo em vista que, não raro, demoram-se décadas para a solução de alguns litígios, ou mesmo após o reconhecimento do direito alegado em juízo e a

${ }^{62}$ TAVARES, Fernando Horta. Tempo e Processo. In: GALUPPO, Marcelo Campos (Org.). O Brasil que queremos: reflexão sobre o Estado Democrático de Direito. Belo Horizonte: PUCMINAS, 2006. v. 1. p. 585-626. 
concessão da tutela jurisdicional, não se consegue efetivar (cumprir) a sentença ou acórdão pela via procedimental executiva.

Foi nesse contexto de insatisfação com a má qualidade e a ineficiência da atividade da prestação jurisdicional que se inseriu no ordenamento jurídico brasileiro o princípio da razoável duração do procedimento e os meios que garantam sua célere tramitação. O escopo dessa inserção foi promover uma verdadeira reforma do judiciário, porque o atual aparato estatal não é capaz de suporta a elevadíssima quantidade de demandas em andamentos em todo o país, ${ }^{63}$ razão pela qual a mesma Emenda à Constituição nº 45 acrescentou ao artigo 93, dentre outros, o inciso XIII, o qual determina que em cada unidade jurisdicional (comarca) o número de magistrados deve ser proporcional à efetiva demanda e à população. Outra medida dessa emenda foi a criação do Conselho Nacional de Justiça, órgão que tem como uma de suas finalidades a fiscalização dos atos dos magistrados.

Outro motivo que se pode mencionar, embora seja menos importante, diz respeito à igual positivação do Direito Fundamental em questão em algumas das principias legislações estrangeiras de países como Itália, Estados Unidos da América, Canadá, Espanha, Chile, Portugal, dentre outros, consoante narra Gustavo Medeiros Melo. ${ }^{64}$

No Brasil, especificamente, já foi mencionada a razoável duração do "procedimento" e os meios que garantam sua célere tramitação é Direito Fundamental dos cidadãos. No entanto, tem sido usado contra estes, uma vez que têm servido de justificativa para as intermináveis reformas processuais, que cada vez mais suprimem direitos das partes, com base na retórica de que imprimirá celeridade à atividade da prestação jurisdicional conferindo poderes aos juízes, em preterição do devido processo. Por essas razões, o princípio em estudo necessita ser interpretado (aplicado) em consonância com os demais direitos fundamen-

${ }^{63}$ Segundo Welington Luzia Teixeira, atualmente, em todo o Brasil, existem mais de 42 milhões de processos em andamentos TEIXEIRA, Welington Luiza. Juiz "faz de tudo". Jornal Estado de Minas, Belo Horizonte, 10 de junho de 2010. Coluna de opinião.

${ }^{64}$ MELO, Gustavo de Medeiros. A tutela adequada na reforma constitucional de 2004. Revista de Processo, São Paulo, v. 30, n. 124, p. 76-110, jun. 2005. 
tais de índole processual (modelo constitucional do processo), um não pode se sobrepor ao outro.

Ronaldo Brêtas de Carvalho Dias também ressalta a importância de interpretar o princípio em questão conforme o modelo constitucional do processo:

[...] a prestação da atividade jurisdicional em tempo útil ou prazo razoável, o que significa adequação temporal da jurisdição, mediante processo sem dilações indevidas, não permite impingir o Estado ao povo a aceleração dos procedimentos pela diminuição das demais garantias processuais constitucionais, por exemplo, suprimir o contraditório, proibir a presença do advogado no processo, eliminar o duplo grau de jurisdição, abolir a instrumentalidade das formas, restringir o direito das partes à produção de provas lícitas ou dispensar o órgão jurisdicional de fundamentar racionalmente suas decisões. A restrição de quaisquer dessas garantias processuais constitucionais, sob a justificativa de agilizar ou tornar célere o procedimento, revela-se inconstitucional $\mathrm{e}$ antidemocrática, somente servindo para estimular o arbítrio dos juízes, fomentar a insegurança jurídica e escarnecer da garantia fundamental do devido processo legal, em resumo, deslavada e grosseira agressão ao princípio constitucional do Estado Democrático de Direito. ${ }^{65}$

Nessa lógica de pensamento e a partir de uma interpretação lógico-sistemática da razoável duração do procedimento e dos demais princípios dos componentes do devido processo legal, além de considerar que, desde 05 de outubro de 1988 , a República Federativa do Brasil se proclamou um Estado Democrático de Direito (art. $1^{\circ}$ da CR/88), tendo como um dos seus fundamentos a soberania popular (art. $1^{\circ}, \S$ único); considerando também que, nessa oportunidade, adotou o sistema jurídico da civil law (art. 5, $\mathrm{II}$ ); considerando, por último, que as Leis processuais estabelecem prazos para a prática dos atos processuais, a razoável duração do procedimento impõe aos magistrados e serventuários o dever de cumprimentos desses prazos. Nada mais é que uma vertente do princípio da legalidade (reserva legal).

\footnotetext{
${ }^{65}$ BRÊTAS, Ronaldo. Direito à jurisdição eficiente e garantia da razoável duração do processo na reforma do judiciário. Revista da Faculdade Mineira de Direito (PUCMG), Belo Horizonte, v. 8, n. 15, p. 230-240, 2005.
} 
Ora, esse direito fundamental não foi inserido no ordenamento jurídico brasileiro por benevolência do legislador ordinário, mas é, como qualquer outro, direito e garantia fundamental, uma conquista teórico-histórica da humanidade que assegura uma limitação da atuação do Estado na esfera privada, determinante de deveres (dever-ser) aos representantes do povo e aos governantes. Logo, não pode o legislador ordinário, dizendo que objetiva concretizar um pretenso (não positivado) direito fundamental ao processo efetivo - que, na verdade, objetiva aumentar os resultados (eficiência) da jurisdição e, por conseguinte, fazer com que o "procedimento" tenha uma razoável duração. Editar leis que acabam por negar o devido processo legal, que é a mais importante das garantias fundamentais. Se assim não for, estar-se-á diante de um grande paradoxo: um direito fundamental dos cidadãos sendo usado contra eles mesmos.

Nesse ponto, cabe mencionar a título de ilustração, demonstrando ainda a utilidade prática do que foi dito no presente trabalho, algumas das principais modificações propostas pelo anteprojeto do novo Código de Processo Civil, uma vez que o objetivo deste é imprimir maior celeridade à atividade de prestação jurisdicional.

\subsection{0 anteprojeto do novo código de processo civil brasileiro e a razoável duração do processo}

Uma das novidades dessa proposta é a criação do instituto da tutela de evidência, o qual encontra respaldo no artigo 285 do anteprojeto do novo Código de Processo Civil (Projeto de Lei do Senado 166/2010). Segundo o referido dispositivo legal e seus incisos, é possível a antecipação dos efeitos de futura sentença de mérito, independentemente da demonstração de dano irreparável ou de difícil reparação, quando ficar caracterizado o abuso de direito de defesa ou o manifesto propósito protelatório do requerido; um ou mais dos pedidos cumulados ou parcela deles mostrar-se incontroverso, caso em que a solução será definitiva; a inicial for instruída com prova documental irrefutável do direito alegado pelo autor a que o réu não oponha prova inequívoca; ou a matéria for unicamente de direito e houver jurisprudência firmada em julgamento de casos repetitivos ou súmula vinculante. 
Esse instituto é mais abrangente que a Tutela Antecipada no CPC vigente, primeiro, porque não se exige a demonstração de perigo de dano irreparável ou de difícil reparação, segundo, porque cria outras situações passíveis de uma proteção jurisdicional diferenciada (não ordinária).

Tal novidade tem relação de certo modo indireta com o direito à razoável duração do procedimento, uma vez que sua principal finalidade é garantia à eficiência (resultado útil) da prestação jurisdicional, além de, é claro, resolver o problema das chamadas "causas repetitivas", o que, certamente, contribuirá para se concretizar o Direito Fundamental à tempestividade da função jurisdicional, pois a decisão de demandas em massa (escala industrial) alivia a sobrecarga de volume de julgamento, principalmente dos tribunais. Nesse sentido, o anteprojeto da novel Lei Processual Civil estabelece, nos seus artigos 895/906, o incidente de resolução de demandas repetitivas, que é diferente do julgamento dos recursos extraordinários e especiais repetitivos, pois aquele tem como pressuposto controvérsia com potencial de gerar relevante multiplicação de processos fundados em idêntica questão de direito e de causar grave insegurança jurídica, decorrente do risco de coexistência de decisões conflitantes.

O problema nesse ponto refere-se ao fato de considerar a existência de matéria unicamente de direito, que, portanto, prescindiria de prova, restringindo, dessa forma, a ampla defesa. Em linhas acima, defendeu-se a inexistência do desdobramento de questões de direito e de fato; porquanto, a situação fática reconstruída, exaustivamente e em contraditório, pelas partes (causa de pedir remota), que, por conseguinte, referem-se aos argumentos jurídicos - alegações de preliminares ou de mérito - articulados com o intuito de se deduzir qual a norma (causa de pedir próxima), entre as prima facie aplicáveis, é adequada ao caso. ${ }^{66}$ Isto é, a norma na qual se funda a pretensão ou a resistência da parte descreve uma situação fática, valorando-a com lícita (faculdade) ou ilícita (obrigação, dever). Sempre existirá

\footnotetext{
${ }^{66}$ GÜNTHER, Klaus. The sense of appropriateness: application discourses in morality and law. New York: State University of New York, 1993.

GÜNTHER, Klaus. Un concepto normativo de coherencia para uma teoría de la argumentación jurídica. Trad. Juan Velasco Arroyo. Doxa: Cuaderno de Filosofia del Derecho, Alicante, n. 17-18, p. 271-302, 1995.
} 
relação entre os fatos (questões de fato) e o direito legitimador da pretensão ou da resistência (questões de direito).

Mas foi o sistema recursal que sofreu um número maior de alterações, o que já era esperado, pois grande parte doutrina e dos operadores do direito culpa, sem justificativa plausível, o sistema recursal do procedimento ordinário do Processo de Conhecimento brasileiro como o grande causador da ineficiência do Judiciário.

Segundo a nova sistemática processual civil não existirá o recurso de Embargos Infringentes (artigo 907 e incisos). Quando houver, então, acórdão não unânime que tenha reformado sentença de mérito, ou julgado procedente ação rescisória o único meio de impugnar tal decisão será mediante Recurso Especial ou Extraordinário, se for o caso.

O recurso de Agravo sofreu mais uma vez limitação nos aspectos quanto ao seu cabimento. Extinguiram-se as modalidades retidas escrita e oral, além de restringir a interposição na forma instrumental apenas contra as decisões interlocutórias que versarem sobre tutelas de urgência ou de evidência; ou sobre o mérito da causa; ou proferidas na fase de cumprimento de sentença ou no processo de execução; ou, por último, quando expressamente previsto pelo Código, consoante se lê no artigo 929, inciso I-IV, do anteprojeto da novel Lei Processual Civil (Projeto de Lei do Senado 166/2010). Não será possível a interposição contra as decisões que causarem grave lesão ou de difícil reparação.

Como ocorrido nas reformas parciais, o direito ao duplo grau de jurisdição tem sido mitigado em nome da celeridade processual, fato que lesa, por conseguinte, o contraditório, ampla defesa e, evidentemente, o devido processo legal, o que não pode acontecer, como conforme dito acima.

Todavia, o parágrafo único do supramencionado artigo determina que não serão atingidas pela preclusão as demais interlocutórias proferidas antes da sentença, podendo ser impugnadas pela parte, em preliminar, das razões ou contrarrazões da apelação. Ou seja, as decisões interlocutórias não impugnáveis mediante agravo de instrumento podem ser atacadas, preliminarmente, no recurso de apelação. 
Outra novidade refere-se ao prazo de interposição dos recursos, eis que na nova sistemática haverá maior prazo, tendo em vista (parágrafo único do artigo 907) que todos os recursos, com exceção dos Embargos de Declaração, serão interponíveis em 15 dias “úteis". Com efeito, não se contará mais o prazo como determinado pela Lei Processual vigente (artigo 179) "prazo estabelecido pela lei ou pelo juiz é contínuo, não se interrompendo nos feriados”. Aqui, em contraposição ao que vinha sendo feito, a ampla defesa foi privilegiada, visto que se terá maior lapso temporal para se preparar as peças processuais, seja por parte do autor ou do réu.

Em linhas gerais e a partir de uma análise perfunctória, são essas as propostas de alterações do novel Código de Processo Civil brasileiro que mais chamaram atenção e mostraram-se relacionadas com o objeto do presente trabalho.

Vê-se, dessa forma, e isso já foi dito, há uma grande preocupação em se alterar as legislações processuais, a fim de concretizar o Direito Fundamental à razoável duração do procedimento. Contudo, não se pode olvidar que este tem como consequência dever(es) ao Estado, em contraposição do exercício do seu "Poder", uno e indivisível, consubstanciado nas suas três essenciais funções, independentes entre si, quais sejam, legislativa, administrativa e jurisdicional, razão pela qual se deve perquirir quais são as implicações lógico-jurídicas trazidas pelo direito à tempestividade da tutela jurisdicional às funções legislativa e à administrativa, até porque o que aqui se pretende defender é que para se efetivar e concretizar o mencionado Direito Fundamental, é preciso uma atuação conjunta das três funções estatais, esclarecendo que aos magistrados e aos serventuários do Judiciário (agentes públicos da função jurisdicional) incumbe-se o cumprimento dos prazos processuais determinados pela lei.

\subsection{Outras implicações}

Mas não é só. O princípio em questão implica outros deveres ao Legislativo e ao Executivo, eis que o texto legal aduz: “[...] a todos, no âmbito judicial e administrativo, são assegurados a razoável duração do processo e os meios que garantam a celeridade de sua tramitação". Nesse sentido, o órgão estatal legiferante tem 
a função de editar regras que determinem prazos razoáveis para a prática de atos processuais, ${ }^{67}$ respeitando o devido processo, principalmente.

As obrigações atinentes à Administração Pública direta - Poder Executivo - dizem respeito à dotação do judiciário, ou seja, a administração pública há que disponibilizar parte de sua receita que seja suficiente para uma boa estruturação do sistema judiciário, o que inclui a contratação (mediante concurso público de provas e títulos) serventuários qualificados e material tecnológico suficiente, ${ }^{68} \mathrm{a}$ fim de lhe dar condições para prestar a tutela jurisdicional no lapso temporal prescrito na lei (razoável duração do procedimento como imposição aos magistrados e aos serventuários à observância dos prazos para realização dos atos processuais que lhes incumbem).

Corroborando a ideia de necessidade de cooperação das três essenciais funções do Estado, representantes do Executivo, Legislativo e Judiciário firmaram, em

${ }^{67}$ MARINONI, Luiz Guilherme. Direito fundamental á duração razoável do processo. Interesse Público, Belo Horizonte, v. 10, n. 51, p. 42-60, set. 2008. Além disto, o autor paranaense entende que o legislador tem a obrigação de prescrever meios judiciais para que as partes controlem as decisões judiciais que violem normas processuais destinadas a tutelar o direito fundamental da razoável duração do "processo", sendo que tal violação ensejaria proposição de ação em desfavor do Estado, com vistas a ressarcir danos patrimoniais e não-patrimoniais causados pela não observância desse preceito; defende, ainda, que se deve conferir poderes aos juízes para que possam distribuir o ônus do tempo do processo. Com todo respeito e moderação, algumas ressalvas precisam ser feitas acerca do posicionamento supramencionado: primeira, não é necessária a positivação de mecanismos para o controle das decisões judiciais que violem as normas de tutela do princípio da razoável duração do procedimento, porque isto se faz pelo DEVIDO PROCESSO - Modelo Constitucional de Processo - já esculpido na nossa Constituição, basta apenas uma melhor compreensão deste instituto; segunda, é evidente que é o Estado é responsável civilmente por suas ações e omissões, além de se cogitar até a responsabilidade pessoal do juiz (Cf. obra de destaque sobre o assunto: BRÊTAS, Ronaldo. Responsabilidade do estado pela função jurisdicional. Belo Horizonte: Del Rey, 2004); terceira, última e mais importante, nas democracias não se pode em hipótese alguma falar em concessão de poderes aos magistrados ou governantes, pois a soberania popular - determinada no parágrafo único do artigo $1^{\circ}$ da Constituição Federal vigente é pressuposto lógico-jurídico das sociedades democráticas. Logo, só a norma construída pelos seus destinatários e, portanto, coautores, é que tem "poder".

${ }^{68}$ MARINONI, Luiz Guilherme. Direito fundamental á duração razoável do processo. Interesse Público, Belo Horizonte, v. 10, n. 51, p. 42-60, set. 2008. 
15 de abril de 2009, o II Pacto Republicano de Estado - que é, ressalta-se, uma série de propostas, fruto da colaboração das três essenciais funções estatais, oportunidade que os representantes de tais funções assumem compromissos para a consecução de determinados escopos - por um sistema de justiça mais acessível, ágil e efetivo do qual, um dos objetivos é atingir a eficiência da atividade de prestação jurisdicional, mediante a eficácia do princípio constitucional da razoável duração do processo:

Firmar o presente PACTO REPUBLICANO DE ESTADO POR UM SISTEMA DE JUSTIÇA MAIS, ÁGIL E EFETIVO, com os seguintes objetivos:

II - aprimoramento da prestação jurisdicional, mormente pela efetividade do princípio constitucional da razoável duração do processo e pela prevenção de conflitos (grifo do autor). ${ }^{69}$

Assumindo-se, dentre outros, os seguintes compromissos, para a consecução de tal objetivo: “[...] melhorar a qualidade dos serviços prestados à sociedade, possibilitando maior acesso e agilidade, mediante a informatização e desenvolvimento de programas de qualificação dos agentes e servidores do Sistema de Justiça”, além de “[...] viabilizar os recursos orçamentários necessários à implantação dos programas e ações previstos neste Pacto" ${ }^{70}$

Além do mais, concedeu prioridades às seguintes matérias, em outras, destaca-se: “[...] revisão de normas processuais, visando a agilizar e a simplificar o processamento e julgamento das ações, coibir os atos protelatórios, restringir as hipóteses de reexame necessário e reduzir recursos”, assim como “[...] o aperfeiçoamento do sistema de execução trabalhista para incorporar aprimoramentos já adotados no processo de execução civil"71 (Pacto Republicano de Estado por um sistema de justiça mais ágil e efetivo, Anexo II, Matérias Prioritárias - Agilidade e efetividade da prestação jurisdicional -, 2.6 e 2.7 )

${ }^{69}$ BRASIL. Presidência da República. II Pacto republicano de Estado por um sistema de justiça mais ágil e efetivo. Diário de Justiça, Brasília, 26 maio 2009.

${ }^{70}$ BRASIL. Presidência da República. II Pacto republicano de Estado por um sistema de justiça mais ágil e efetivo. Diário de Justiça, Brasília, 26 maio 2009.

${ }^{71}$ BRASIL. Presidência da República. II Pacto republicano de Estado por um sistema de justiça mais ágil e efetivo. Diário de Justiça, Brasília, 26 maio 2009.

Anexo II, Matérias Prioritárias - Agilidade e efetividade da prestação jurisdicional -, 2.6 e 2.7 . 
Postas essas considerações e o referido Pacto Republicano de Estado é uma prova disso, conclui-se, em resumo, que a eficácia do dispositivo em questão pressupõe atuação conjunta das três funções do Estado (Jurisdicional, Legislativa e Executiva ou Administrativa), sendo que ao primeiro cabe a aplicação cogente da lei processual, respeitando, assim, os prazos processuais para a realização de atos processuais que lhe incumbe; ao Legislador ordinário compete respeitar os Direitos e Garantias Fundamentais dos cidadãos, editando, por conseguinte, leis que os observem e estabeleçam prazo razoável, tanto para as partes quanto para os juízes e seus auxiliares, para a prática de atos processuais; ao Executivo incumbe a dotação de pessoal e de material tecnológico do primeiro.

É essa a compreensão constitucionalmente adequada da razoável duração do procedimento, tendo em vista que, conforme já mencionado, um direito fundamental, pelo seu caráter de conquista histórico-teórico da humanidade garantidor de uma limitação do Estado na esfera privada e determinante de deveres a este (Estado). Se assim não for, a tão aclamada celeridade da prestação jurisdicional nunca será alcançada, sendo que as alterações das leis processuais em nada adiantarão, visto que, por si só, não têm o condão de alterar coisa alguma.

\section{Considerações finais}

Em face de todas essas considerações, uma coisa é certa, essas inúmeras alterações no Código de Processo Civil não resolveram nem resolverão sozinhas o problema da morosidade da atividade jurisdicional. A solução desse problema diz respeito à Administração Pública, não ao Legislador. O cerne da questão é muito mais estrutural e administrativo do que legislativo. Exige-se uma atuação conjunta do Executivo, Legislativo e do Judiciário. É certo que algumas das alterações já em vigor ajudaram, mas só essas alterações não são suficientes, nem mesmo uma reforma total das Leis Processuais, porque a Lei, per se, não tem o condão de modificar a estrutura de um Judiciário que precisa atender uma complexa e moderna sociedade como a brasileira. 
Nessa linha de pensamento, é preciso esclarecer o que se pretende: se é alcançar a efetividade do processo ou a eficiência da prestação jurisdicional. Se o desiderato for atingir a efetividade processual, basta aplicar a Constituição no que se refere aos direitos fundamentais caracterizadores do processo. Mas se o objetivo for fazer com que a prestação jurisdicional seja eficiente (leia: produza os resultados esperados), impõe-se uma atuação conjunta do Judiciário, Legislativo e Executivo, conforme mencionado acima, o que também passa, essencialmente pelos preceitos constitucionais.

Além do mais, se for levado em consideração o princípio da supremacia constitucional, toda modificação da legislação vigente, baseada na retórica de que se imprimirá celeridade à atividade de prestação jurisdicional - alcançando, por consequência, a razoável duração do procedimento - conferindo poderes aos magistrados, em detrimento das garantias processuais, lesará o modelo constitucional do processo, ensejando a declaração de sua inconstitucionalidade.

Não se pode olvidar que o "tempo do processo" é inferido do procedimento, tendo como variável-determinante a prova a ser produzida, isto é, o procedimento probatório.

De conseguinte, a ideia de razoável duração do procedimento aqui defendida implica imposição (dever-legal) aos magistrados e serventuários, cuja inobservância acarreta responsabilidade do Estado e até mesmo pessoal do agente público, caso se verifique a ocorrência de danos. Nessa perspectiva, inexistiriam os esdrúxulos prazos impróprios, maiores causadores das "etapas mortas" do processo e geradores da morosidade da jurisdição. 


\title{
The procedural reforms and due process of law: incursions about the reasonable lenght of the procedure and the effectiveness procedural in democratic process
}

\begin{abstract}
This research aims to study the effectiveness procedural and the implications brought by the guaranty of reasonable length of process, because these institutes has been understood wrongly, serving of subterfuge to the State, because, under the argument of that the process has to have reasonable length and, consequently, the effectiveness procedural, it has altered the procedural legislation, with an aim of suppress procedural guaranties, instead of structure The Judiciary. For that, is needed conceptualize the institute of Due Process of Law, to understand it accordingly to Democratic State. Then, will be worked the factor "Time" and the theory of effectiveness procedural on the principles of process. Lastly, will be presented a contradict to traditional understanding of what is factors determines the reasonable length of process, showing which the variable-determiner for the Time of procedure.
\end{abstract}

Keywords: Due process of law. Reasonable length of process. Effectiveness procedural. Constitutionals principles of process. Rights and guaranties fundamentals.

\section{Referências}

BARROS, Flaviane de Magalhães. (Re)forma do processo penal: comentários críticos dos artigos modificados pelas leis n. 11.690/08 e n. 11.719/08. Belo Horizonte: Del Rey, 2008.

BARROS, Flaviane de Magalhães; CARVALHO, Marius Fernando Cunha de; GUIMARÃES, Natália Chernicharo. O princípio da ampla defesa: uma reconstrução a partir do paradigma do estado democrático de direito. Provocações, Sete Lagoas, MG, n. 2, p. 35-51, jan./dez. 2006.

BARROS, Flaviane de Magalhães. O processo, a jurisdição e a ação sob ótica de Elio Fazzalari. Virtuajus: Revista Eletrônica da Faculdade Mineira de Direito, Belo Horizonte, ano 2, p. 1-29, 2003. 
BRASIL. Presidência da República. II Pacto republicano de Estado por um sistema de justiça mais ágil e efetivo. Diário de Justiça, Brasília, 26 maio 2009.

BRÊTAS, Ronaldo. As reformas do Código de Processo Civil e o modelo constitucional do processo. In: BRÊTAS, Ronaldo; NEPOMUCENO, Luciana (Org.). Processo civil reformado. 2. ed. Belo Horizonte: Del Rey, 2009. v. 1. p. 457-496.

BRÊTAS, Ronaldo. Direito à jurisdição eficiente e garantia da razoável duração do processo na reforma do judiciário. Revista da Faculdade Mineira de Direito (PUCMG), Belo Horizonte, v. 8, n. 15, p. 230-240, 2005.

BRÊTAS, Ronaldo. Exame técnico e sistemático do Código de Processo Civil reformado. In: BRETAS, Ronaldo; NEPOMUCENO, Luciana (Org.). Processo civil reformado. 2. ed. Belo Horizonte: Del Rey, 2009. v. 1. p. 407-456.

BRÊTAS, Ronaldo. Fraude no processo civil. 3. ed. Belo Horizonte: Del Rey, 2001.

BRÊTAS, Ronaldo. Responsabilidade do estado pela função jurisdicional. Belo Horizonte: Del Rey, 2004.

CÂMARA, Alexandre Freitas. Lições de direito processual civil. 20. ed. rev. e atual. Rio de Janeiro: Lumen Juris, 2010.

CATTONI DE OLIVEIRA, Marcelo Andrade. Jurisdição e hermenêutica constitucional no Estado democrático de Direito; um ensaio de teoria da interpretação enquanto teoria discursiva da argumentação jurídica de aplicação. In: OLIVEIRA, Marcelo Andrade Cattoni de (Org.). Jurisdição e hermenêutica constitucional no estado democrático de direito. Belo Horizonte: Mandamentos, 2004. p. 47-78.

CINTRA, Antônio Carlos de Araújo; GRINOVER, Ada Pellegrini; DINAMARCO, Cândido R. Teoria geral do processo. 24. ed. rev. e atual. São Paulo: Malheiros, 2008.

DINAMARCO, Cândido Rangel. A instrumentalidade do processo. 5. ed. São Paulo: Malheiros, 1996.

FAZZALARI, Elio. Instituições de direito processual. Tradução de Elaine Nassif. Campinas: Bookseller, 2006.

GONÇALVES, Aroldo Plínio. Técnica processual e teoria do processo. Rio de Janeiro: Aide, 1992. 
GÜNTHER, Klaus. The sense of appropriateness: application discourses in morality and law. New York: State University of New York, 1993.

GÜNTHER, Klaus. Un concepto normativo de coherencia para uma teoría de la argumentación jurídica. Trad. Juan Velasco Arroyo. Doxa: Cuaderno de Filosofia del Derecho, Alicante, n. 17-18, p. 271-302, 1995.

HABERMAS, Jürgen. Direito e democracia: entre facticidade e validade. Rio de Janeiro: Tempo Brasileiro, 1997. (Biblioteca Tempo Universitário, 101-102).

LEAL, Rosemiro Pereira. Teoria geral do processo: primeiros estudos. 8. ed. rev. e atual. São Paulo: Forense, 2009.

LEAL, Rosemiro Pereira. Teoria processual da decisão jurídica. São Paulo: Landy, 2002.

MACIEL JUNIOR, V. P. Estrutura e interpretação do direito processual civil brasileiro a partir da Constituição Federal de 88. In: MACHADO, Felipe Daniel Amorim; OLIVEIRA, Marcelo Andrade Cattoni de (Org.). Constituição e processo: a contribuição do processo ao constitucionalismo democrático. [S.l.: s.n.], 2008. p. 292-311.

MARINONI, Luiz Guilherme. Direito fundamental á duração razoável do processo. Interesse Público, Belo Horizonte, v. 10, n. 51, p. 42-60, set. 2008.

MARINONI, Luiz Guilherme. Efetividade do processo e tutela de urgência. Porto Alegre: S. A. Fabris, 1994.

MELO, Gustavo de Medeiros. A tutela adequada na reforma constitucional de 2004. Revista de Processo, São Paulo, v. 30, n. 124, p. 76-110, jun. 2005.

NERY JÚNIOR, Nelson. Princípios do processo civil na Constituição Federal. 8. ed. rev. ampl. e atual. São Paulo: Revista dos Tribunais, 2004.

NUNES, Dierle José Coelho. Processo jurisdicional democrático: uma análise crítica das reformas processuais. Curitiba: Juruá, 2008.

RIBEIRO, Fernando José A.; BRAGA, Barbara. A aplicação do direito na perspectiva hermenêutica de Hans-Georg Gadamer. Revista da Faculdade Mineira de Direito (PUCMG), Belo Horizonte, v. 11, p. 121-143, 2008. 
SILVA, Ovídio A. Baptista da. O contraditório nas ações sumárias. Revista Jurídica: Órgão Nacional de Doutrina, Jurisprudência, Legislação e Crítica Judiciária, Porto Alegre, v. 49, n. 287, p. 5-29, set. 2001.

SOUZA, Joaquim Adelson Cabral de. O discurso da efetividade processual na contemporaneidade brasileira. 2009. 162 f. Dissertação (Mestrado)-Programa de Pós-Graduação em Direito, Pontifícia Universidade Católica de Minas Gerais, Belo Horizonte, 2009.

TAVARES, Fernando Horta. Tempo e Processo. In: GALUPPO, Marcelo Campos (Org.). O Brasil que queremos: reflexão sobre o Estado Democrático de Direito. Belo Horizonte: PUCMINAS, 2006. v. 1. p. 585-626.

TEIXEIRA, Welington Luiza. Juiz “faz de tudo". Jornal Estado de Minas, Belo Horizonte, 10 de junho de 2010. Coluna de opinião.

THEODORO JÚNIOR, Humberto. Celebridade e efetividade da prestação jurisdicional. Insuficiência da reforma das leis processuais. Revista de Processo, São Paulo, v. 30, n. 125, p. 61-78, jul. 2005.

TUCCI, José Rogério Cruz e. Tempo e processo: uma análise empírica das repercussões do tempo na fenomenologia processual (civil e penal). São Paulo: Revista dos Tribunais, 1997. 